\title{
Sugarcane Farmers' Perception, Challenges and Response to Climate Change in Kaduna State, Nigeria
}

\author{
${ }^{1}$ Suleiman Musa Balarabe, ${ }^{2}$ Ikpe Elisha and ${ }^{3}$ Mohammed Dayyabu \\ ${ }^{I}$ Department of Local Government and Development Studies, Ahmadu Bello University, Zaria \\ ${ }^{2}$ Department of Geography, Ahmadu Bello University, Zaria \\ ${ }^{3}$ Department of General Studies, Nuhu Bamalli Polytechnic, Zaria
}

\begin{abstract}
Sugarcane production is important to the economic development of Kaduna State. It has contributed greatly in creating employment and serving as sources of income to farmers and the government. However, like other parts of the world, sugarcane production in Kaduna state is greatly affected by climate change. This paper therefore focused on the perception, challenges and response by sugarcane farmers to climate change in Lere Local Government Area of Kaduna State. A total of 200 farmers were randomly sampled and administered questionnaire in the Local Government Area. The results were summarized and presented by means of frequencies and percentages in tabular forms and charts. The study revealed that 58\% of the farmers have perceived the continuous increase in temperature which has positively increased sugarcane growth during the dry season, although, such temperature increase has resulted in increased irrigation needs; prevalence of weeds, diseases and insect pests of sugarcane; increase in rainfall amount in recent years has resulted to devastating floods which usually destroyed most of the sugarcane farms and sometimes washed away the entire farmlands along the floodplains; water stress is experienced during the dry season. While inadequate access to water for irrigation and information on weather forecasting and lack of knowledge on emerging adaptation methods are some of the challenges farmers are faced with. The study further revealed several adaptation measures adopted by the farmers to cope with the effects of climate change, among which are; introduction of new hybrid-black sugarcane; local boreholes and planting of trees along river valleys to prevent landslide. The study recommended the need for climate change awareness/education by relevant authorities; creation of small earth dams; government and NGOs interventions to sugar cane farmers in form of loans, grants and subsidies to boost sugarcane production in the study area.
\end{abstract}

Key Words: Adaptation strategies, challenges, climate change, perception, sugarcane farmers.

\section{Introduction}

Climate change refers to a change in the state of the climate that can be identified by changes in the mean and/or the variability of its properties and that persists for an extended period, typically decades or longer (IPCC, 2007). It refers to any change in climate over time, whether due to natural variability or as a result of human activity. Climate change impacts necessitate responses and adjustments to the biophysical and social conditions which together determine exposure to climate hazards. These responses may occur in form of autonomous action or through public as well as private planned, individual and institutional mechanisms. Sugarcane farmers respond to climate change through adaptation. Adaptation is the ecological, social, or economic systems in response to actual or expected climate stimuli and their impacts. Adaptation refers to changes in processes, practices, or structures to moderate or offset potential damages or to take advantage of opportunities associated with changes in climate (IPCC, 2001). Adaptation involves adjustments to reduce the vulnerability of communities, regions or activities to climatic change and variability. Adaptation is important in the climate change issue in two ways: one, to assess the impacts and vulnerabilities, two, to develop and evaluate adaptation options (Smit and Skinner, 2002).

Perception is a process by which organisms interpret and organize sensation to produce a meaningful experience of the world. Perception is the process by which we receive information or stimuli from our environment and transform it into psychological awareness (UNEP 1998). Pointedly, the Oxford Dictionary defines perception "as the way in which something is regarded, understood or interpreted". In this study, sugarcane farmers' perceptions will be understood as different understandings, and/or utterances with regards to climate change deliberations. As can be imagined, these vary from person to person. Perceiving climate variability is the first step in the process of adapting agriculture to climate change (Deressa, Hassa and Ringler, 2011). A better understanding of farmers' concerns and the manner in which they perceive climate change is crucial to design effective policies for supporting successful adaptation of the agricultural sector. Further, it is also important to have precise knowledge about the type and extent of adaptation methods being taken up by farmers and need for further advances in existing adaptation setups. Hence, understanding how farmers perceive 
changes in climate and what factors shape their adaptive behavior is useful for adaptation research (Mertz, Mbow, Reenberg and Diouf, 2009; Weber, 2010)

There is a growing understanding that climate change poses serious challenges to agricultural development in Nigeria. The reason for this is that the mainstay of agriculture in Nigeria is rain-fed agriculture, which is heavily sensitive to climate change and variability. In Nigeria, the traditional and predominant method of clearing farm land is through bush burning. These activities increase the concentrations of greenhouse gases (GHGs) in the atmosphere trapping heat and causing global warming, climate change and sea level rise (Medugu, 2009).

Further, there is the problem of deforestation. Garba, (2006) noted that one of the major causes of poverty is destruction of natural resources, leading to environmental degradation, high temperature, drought and consequently reduced productivity. As global warming accelerates, it is expected that agricultural adaptation to climate change can only be meaningful, if irrigated agriculture gains prominence (Anselm and Taofeeq 2009). The consequences are that the increasing frequency and severity of droughts are likely to cause: crop failure; high and rising food prices; distress sale of animals; de-capitalization, impoverishment, hunger, and eventually famine.

Land tenure and fragmentation systems could also limit the capacity of farmers to adapt to climate change. Among most Nigerian farmers, farmland is not owned but held in trust by the present generation on behalf of their future descendants. The fragmented nature of farmland could hamper the farmers' capacity to adopt innovative farming practices that may be necessary for climate change adaptation. IFAD (2010) reported that about $90 \%$ of Nigeria's food is produced by smallholder farmers who cultivate small plots of land, usually less than 1 hectare of land per household.

The prices of most agricultural export commodities have been falling in recent times as a result of decline in international prices. The farmers' incomes (producer prices) from export will therefore be static at best, if not dropping; hence, it becomes fairly difficult to sustain production (Anselm and Taofeeq 2009).

In addition, lack of access to loan or savings is another challenge farmers are faced with in the study area. The result of a study conducted by Centre for Environmental Economics and Policy in Africa across African countries showed that lack of access to credit or saving is one of the major problems encountered by farmers in adapting to the effects of climate change. According to Ikpe, Sawa, Idoma, Ejeh and Meshubi (2016), lack of money is a major constraint to adaptation by farmers.

Inconsistent agricultural policies: Anselm and Taofeeq (2009) stated that weak infrastructure and inconsistency in government policies have always been major snags in the development of agriculture in Nigeria. More so, at the moment, there are scanty and ill-equipped weather stations and agricultural infrastructure (Odjugo, 2010). The World Bank (2006) reported the existence of inadequate storage facilities and dilapidating agricultural infrastructure in Nigeria. The shortage of storage facilities poses serious threats to farmers in food preservation, most especially during harvest periods. As a result, most farmers are often in a rush to send farm produce to market immediately after harvest, not minding the associated low prices. This could act as a disincentive to investment in agriculture and hence portend serious threats to agricultural adaptation to climate change, (Mogues, et al. 2008).

Lack of education, information and training is frequently a key limiting factor to smallholder development. The report of IFAD (2010) confirmed that the poor state of the country's education has also had its toll on the poor people, majority of who are farmers in rural areas. In addition, they are faced with limited social services and infrastructure. FAO (2008) reported that about 90 per cent of Nigeria's food is produced by smallscale farmers who cultivate small plots of land and depend on rainfall rather than irrigation systems as a result of their low knowledge base, access to facilities and poor financing.

Ikpe, et al. (2016), noted that farmers in Sokoto State are faced with the problem of lack of current knowledge on adaptation methods as a challenge to adaptation strategies; lack of access to water for irrigation; lack of improved seeds; inadequate information on weather incidence and lack of access to credit facilities.

In Nigeria, sugarcane is an annual crop that depends on rainfall and irrigation. According to Gawander (2007), the amount and duration of precipitation, humidity, moisture content, temperature and soil condition has great impact on sugarcane production. Sugarcane production is an important agricultural activity in Northern Nigeria. According to Kaduna State Agricultural Development Project (2013), sugarcane is produced and sold in many local government areas (LGAs) of the state, which includes Makarfi, Giwa, Lere, Kubau and Kudan. About twenty thousand $(20,000)$ households in the state grew sugarcane in 2013 . This indicated that many employment opportunities are available within the sugarcane industry. Given these contributions, any factor affecting the industry has an impact on its contribution to the total GDP of agriculture and hence to the overall economy. Just like other agricultural sectors, sugarcane farming is expected to be affected by climate change (Deressa, Hassan and Poonyth, 2005). Several studies have been conducted to assess the impacts of climate change on agriculture, (e.g. Nzeadibe et al., 2011; Ishaya and Abaje, 2008; Apata, Samuel and Adeola 2009; Nze and Eboh, 2011). Most of these studies paid more attention on farmers' perception and adaptation strategies 
to climate change on rain-fed crops unlike sugarcane production which depends on rainfall and irrigation. To the best of the researchers' knowing, there has not been any study to assess the impacts of climate change on sugarcane production and adaptation strategies in the study area. Thus, a paucity of the study - Sugarcane farmers' perception, challenges and response to climate change in Kaduna state was carried out.

\section{Study Area}

The study Area (Lere Local Government) is located between latitudes $9^{0} 30^{\prime} \mathrm{N}$ and $10^{0} 10^{\prime} \mathrm{N}$, longitude $7^{0} 20^{\prime} \mathrm{E}$ and $8^{0} 00^{\prime} \mathrm{E}$ (see figure 1). The local government is bounded by Kano State and Kubau LGA to the north; Bauchi and Plateau States to the east, Kauru LGA of Kaduna State to the west. It has a total landmass of $2567 \mathrm{sq} . \mathrm{Km}^{2}$ and population of 331,161 (NPC, 2006). The LGA experiences a tropical continental type of climate with distinct wet and dry seasons. The area has a mean annual rainfall of $1,500 \mathrm{~mm}$ and mean monthly temperature rising from $22^{\circ} \mathrm{C}$ in January and attaining a maximum of $32^{\circ} \mathrm{C}$ in April. The relief of the area is generally undulating, varying in altitude from $600 \mathrm{~m}$ to $850 \mathrm{~m}$ above sea level. The area is surrounded by Kudaru hills on western part rising up to $2,600 \mathrm{~m}$, Yage hills to the northeast which rises up to $2,800 \mathrm{~m}$ above sea level which forms the boundary with Bauchi State. The soils of the study area are basically derived from the basement complex rocks. The soils are basically leached ferruginous tropical soils, Wikipedia (2014).

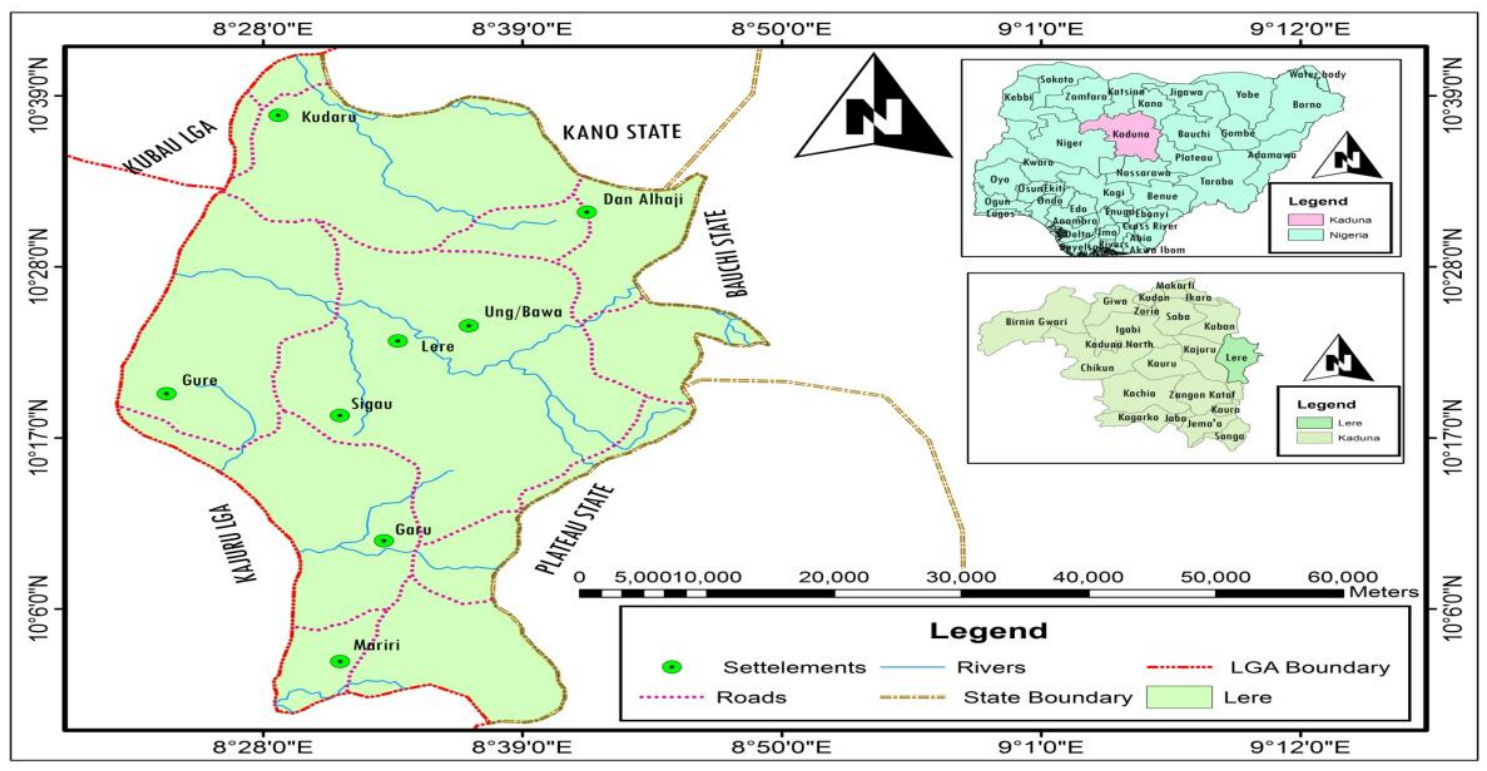

Figure 1: Map of the study area

The Local Government is dissected by many rivers: rivers Rahama, Garu, Mariri, Karambana and river Gurza. These rivers and their tributaries are largely ephemeral in character and their flow regimes are highly irregular following rainfall events in the stream. Several other small streams which are the tributaries of the major rivers are found in the area. The rivers are characterized by extensive flood plains that favour the cultivation of rice, sugarcane and tomatoes in commercial quantity. The head waters of most of the rivers are experiencing gully erosion, Wikipedia (2014).

\section{Materials And Method}

Purposeful sampling technique was used to determine the respondents for the study. Households' Heads above twenty (20) years that were willing and concerned to make relevant contributions to the study regarding the incidence of climate change in the study area were purposively selected. Two hundred (200) respondents were selected and administered questionnaire from twenty (20) sugarcane farming villages in the study area (Mariri, Wauna, Gamagira, Lere, Sugau, Wauna, Lazuru, Juran Kari, Unguwan Zakari, Damau, Marji, Lugura, Jamaan Iya, Garu, Babban Fadama, Dallahaji 1, Dallahaji 2, Waila and Tudai). Only villages that were easily accessible were randomly selected. The two hundred (200) questionnaire were shared proportional to the population of each village, but due to the non-availability of population figures for each village from the 1991 and 2006 census results, the questionnaire were distributed equally among the twenty (20) villages. Ten (10) questionnaires were administered in each of the sugar cane farming communities. Out of the 200 copies of the questionnaires administered in the field, a total of 191 copies were retrieved and analyzed. The data were analyzed and presented using tables, percentages and charts. 
Sugarcane Farmers' Perception, Challenges and Response to Climate Change in Kaduna State, ..

IV. Results And Discussions

Table 1: Personal Data of the Respondents

\begin{tabular}{llcc}
\hline Parameters & Options & No. of Respondents & Percentages (\%) \\
\hline Age (years) & $20-30$ & 63 & 33 \\
& 31 and above & 128 & 67 \\
Gender & & $\mathbf{1 9 1}$ & $\mathbf{1 0 0}$ \\
& Male & 183 & 96 \\
\multirow{3}{*}{ Level of education } & Female & 08 & 4 \\
& & $\mathbf{1 9 1}$ & $\mathbf{1 0 0}$ \\
& SSCE/GII & 61 & 32 \\
& Degree/HND & 02 & 1 \\
& NCE/Diploma & 05 & 3 \\
& No Formal Education & 123 & 64 \\
\hline
\end{tabular}

Source: Field Work 2015

Table 1 showed that majority of the respondents (67\%) falls between the ages of 30 years and above. This is an indication that the respondents were quite qualified to give information about the changes that is occurring in their environment. $96 \%$ of the sampled farmers were males while $4 \%$ were females. The results also showed that majority of the respondents $(64 \%)$ did not attend formal education; this is followed by those that obtained only SSCE certificate or Grade II (32\%), while $1 \%$ of the respondents are first degree holders.

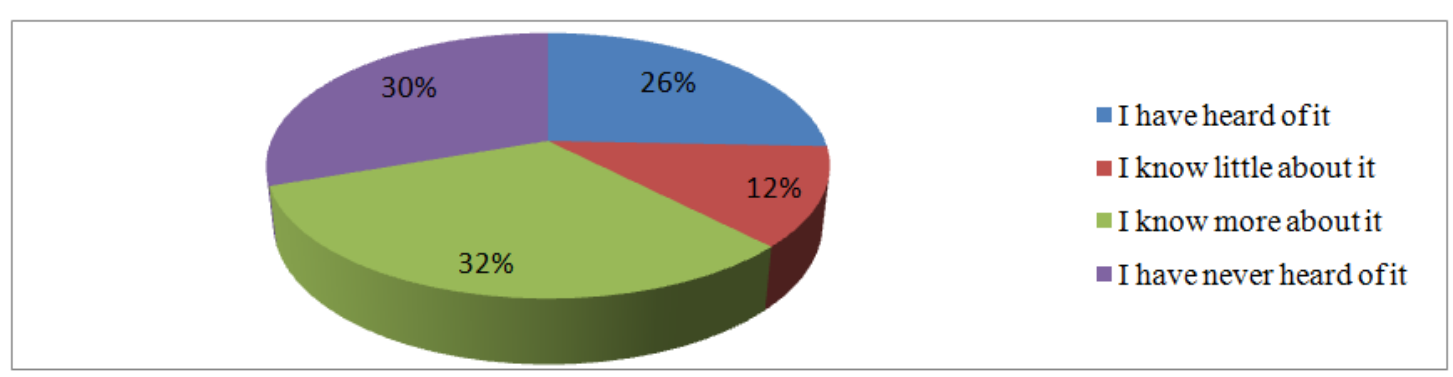

Source: Field Work 2015

Figure 2: Climate Change Awareness among Sugarcane Farmers

Figure 2 showed that $32 \%$ of the respondents reported that they know much about climate change, $30 \%$ said they have never heard of it, while only $12 \%$ reported that they know little about climate change in the study area. The results indicated that the farmers are aware of climate change in the study area. Concerning their sources of information about climate change issues, $64 \%$ reported that they obtained their information on climate change from radio, $16 \%$ from television, while $20 \%$ from the internet, newspaper and other printed materials like fliers and posters.

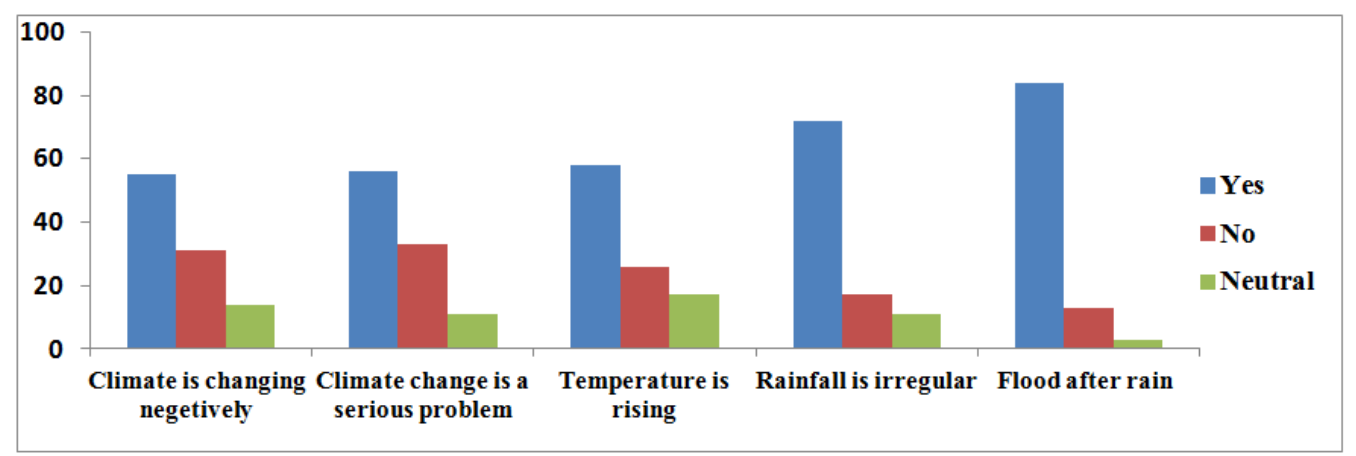

Source: Field Survey, 2015

Fig. 3: Climate Change Perception among Sugarcane Farmers

As shown in Fig. 3, the results of the study showed that $55 \%$ of the respondents reported that climate change has negative effects on their environment; $31 \%$ reported that the climate is not changing negatively. $56 \%$ perceived climate change as a very serious problem in the environment; $33 \%$ reported that climate change is not a problem at all. Again, 58\% of the respondents agreed that temperature in their environment is rising seriously, while $26 \%$ reported that there is no temperature increase; $73 \%$ of the respondents agreed that rainfall is becoming irregular and unpredictable each year and $84 \%$ observed that there has been an incidence of flood 
after rain of recent. The findings here are in agreement with scientific findings (Odjugo, 2009, 2010, 2011; Idowu, Ayoola and Ikenweiare 2011; Mishek, 2013), which reported the indicators of climate change as increasing temperature, irregular and unpredictable pattern of rainfall including prolong dry-spells, acute drought among others.

Table 3: Adaptation Strategies by Sugarcane Farmers

\begin{tabular}{|c|c|}
\hline Adaptation Option & Yes \\
\hline 1. Introduction of new hybrid black sugarcane breed & $90 \%$ \\
\hline 2. $\quad$ Small earth dams using used-cement bags to block streams & $54 \%$ \\
\hline 3. Use of local implements to dig the dry river valley for water & $65 \%$ \\
\hline 4. Digging of local bore-holes & $83 \%$ \\
\hline 5. Use of Pumping machines to replace local method of pumping water & $92 \%$ \\
\hline 6. $\quad$ Planting of trees along river valleys to prevent landslide & $41 \%$ \\
\hline 7. Shifting away from land that is prone to landslide & $55 \%$ \\
\hline 8. Use of chemical fertilizer to boost sugarcane yield & $95 \%$ \\
\hline 9. $\quad$ Mulching to protect sugarcane from water loss & $61 \%$ \\
\hline
\end{tabular}

\section{Source: Field Survey, 2015}

Sugarcane farmers in Kaduna state adopt several adaptation strategies as a way of coping with the impacts of climate change on sugarcane production in the study area. Table 2 illustrated the several adaptation strategies by sugarcane farmers to cope with the impacts of climate change. $90 \%$ of the respondents reported that they have replaced the traditional breed of sugarcane with a more improved variety which is capable of enduring the harsh climatic condition of the environment; 54\% reported that in order to cope with extreme water shortage during the dry season, they usually create local earth dams by blocking the streams with used bags of cement filled with sand and then utilize the water in the dam during water stress. In line with this also, majority of the respondents use local implements, like hoes (small and big), shovels etc. to dig the dry river valley for boreholes during water stress in search of water for irrigation. 92\% reported that they use modernized pumping machines which presently replace the use of buckets for watering the sugarcane farms during the dry season.

To prevent the river banks from excessive landslides, $41 \%$ reported that they plant trees and cover crops along it while 55\% reported that they shifts away from any area that is prone to flood and landslide each year. $94 \%$ of the respondents affirmed that they use chemical fertilizers. The chemical fertilizers were found to be very effective in making the sugarcane stick to grow bigger and taller ahead of the water level during the excessive flood. Also, $61 \%$ of the respondents were discovered to practice mulching which helps to prevent sugarcane roots from excessive water loss during the dry season period.

\section{Sugar cane farmers' challenges to climate change adaptation}

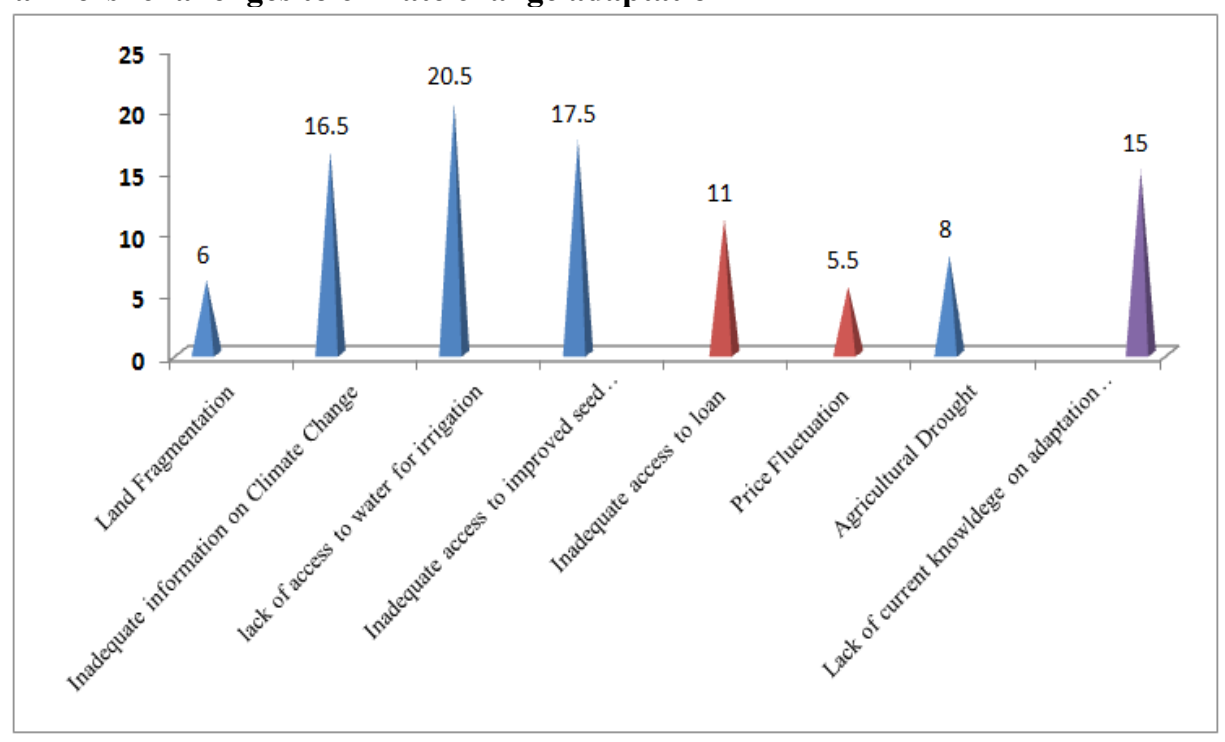

Fig. 4: Sugar Cane farmers' challenges to climate change

\section{Source: Field work 2016}

The analysis of the challenges encountered by the sugarcane farmers in the study area is shown in Fig. 4. The common challenges as analyzed are lack of access for irrigation, inadequate access to improved seed varieties, and inadequate information on weather related issues, lack of current knowledge on adaptation strategies, price fluctuation and agricultural drought. 


\section{Summary of the Findings}

The study has evaluated the sugarcane farmers' perception, challenges and response to climate change in Kaduna state. The study has achieved to a large extent the objective of the study which is to find out the level of awareness on climate change, how sugarcane farmers respond to climate change and the challenges the farmers faced in cultivating sugar cane in the study area.

The study revealed that $58 \%$ of the farmers have perceived the continuous increase in temperature which has positively increased sugarcane growth during the dry season, although, such temperature increase has resulted in increased irrigation needs; temperature increase has led to the prevalence of weeds, diseases and insect pests of sugarcane; increase in rainfall amount in recent years has resulted to devastating floods which usually destroyed most of the sugarcane farms and sometimes washed away the entire farmlands along the floodplains; water stress is experienced during the dry season. While inadequate access to water for irrigation and information on weather forecasting and lack of knowledge on adaptation methods are some of the challenges farmers are faced with. The study revealed several adaptation measures adopted by the farmers to cope with the effects of climate change, among which are; introduction of new hybrid-black sugarcane; local boreholes and Planting of trees along river valleys to prevent landslide.

\section{Recommendations}

Based on the findings made in the study, the following recommendations are made:

1) There is need to raise more awareness on climate change in the area. Government agencies and NGOs can help to educate the Nigerian farmers and the general public on the reality and impacts of climate change on the environment, agriculture, human and animal health.

2) There is need for government's intervention in providing funds to the farmers to boost their sugarcane production. The funds can be in the form of loans, grants or subsidies.

3) Construction of standard dams with well-connected drainage channels across the farmlands is imperative in the area as this will enable the farmers to make use of the available water in the dams during water deficit in the area.

4) There is need to build artificial levees alongside most of the streams in the area to prevent the destructive annual flood. This can be done by the Government, NGOs or the collaboration of both.

5) There is need for government, NGOs and the farmers to provide new farming technologies in the area. Tractors, giant pumping machines, standardized boreholes and fertilizers should be provided to farmers at subsidized rate.

6) Government policies should therefore ensure that farmers have access to improved seed varieties, chemical fertilizer, water for irrigation and affordable credit as these increases the resilience of farmers to climate variability.

7) Farmers' education development on new mitigation and adaptation to climate change should be ensured through extension agents in the area. The farmers should be educated on the importance of tree-planting and dangers of felling tree without replanting.

\section{References}

[1]. IPCC, Climate Change 2007: Impacts, adaptation and vulnerability. Contribution of working group II to the fourth assessment report of the Intergovernmental Panel on Climate Change (Parry, Martin L., Canziani, Osvaldo F., Palutikof, Jean P., Vander Linden, Paul J., and Hanson, Clair E. (eds.)) Cambridge University Press, Cambridge, U.K (2007).

[2]. IPCC, The report of working group II of the intergovernmental panel on climate change survey for policymakers. IPCC, 2001, 879 $-884$

[3]. B Smit and M Skinner, Adaptation options in agriculture to climate change: a typology. mitigation and adaptation strategies for global change, African Journal of Agriculture and Resource Economics, 3(5), 2002, 78-82.

[4]. UNEP, Handbook on methods for climate impact assessment and adaptation strategies (Amsterdam, Netherlands, United Nations Environment Programme, Institute for Environmental Studies, 1998), 359.

[5]. T Deressa, R. M Hassan and C. Ringler, Perception of and adaptation to climate change by farmers in the Nile basin of Ethiopia, Journal of Agricultural Science, 149, 2011, 23-31.

[6]. O Mertz, C. Mbow, A. Reenberg and A. Diouf, Farmers' perceptions of climate change and agricultural adaptation strategies in Journal of Rural Sahel, Environmental Management, 43, 2009, 804-816.

[7]. E. U Weber, What shapes perceptions of climate change? Wiley Interdisciplinary Reviews: Climate Change, 1, 332-342.

[8]. N I. Medugu, Nigeria: climate change - a threat to the country's development, 2009, available at http://www.allafrica.com/nigeria/

[9]. A. Garba, Alleviating poverty in northern Nigeria: A tutorial review, Proc. Annual Convention of Zumunta Association at Minneapolis United State of America, 2006.

[10]. A. E. Anselm and A. A Taofeeq, Challenges of agricultural adaptation to climate change in Nigeria: a Synthesis from the literature: A tutorial review, Proc. conference on Enugu, Nigeria, 2010.

[11]. E Ikpe, B. A Sawa, K. Idoma, L. Ejeh and A. Meshubi, Shift in crop production as an adaptation strategies to climate change by grain farmers in Goronyo local government area of Sokoto state, International Journal of Science for Global Sustainability, 2(1), 2016, $106-113$

[12]. P. A Odjugo, Shift in crops production as a means of adaptation to climate change in the semi-arid region of Nigeria international Journal of Meteorology and Climate Science, 8(1), 2010, 1-6. 
Sugarcane Farmers' Perception, Challenges and Response to Climate Change in Kaduna State, ..

[13]. World Bank, Nigeria: competitiveness and growth, 2006 Report (New York, jointly prepared with DfID, Africa Region), 2006.

[14]. T. Mogues, M. Morris, L. Freinkman, A. Adubi, S. Ehui, C. Nwoko, O. Taiwo, C. Nege, S. P Okonji and L. Chete, Agricultural public spending in Nigeria: A Review, Proc. International Food Policy Research Institute Discussion, 2008, Paper 00789.

[15]. IFAD, Rural poverty in Nigeria: agriculture in the federal republic of Nigeria. International Fund for Agricultural Development, 2010, from http://www.ruralpovertyportal.org/web/guest.

[16]. FAO, Hunger on the rise (New York, Food and Agriculture Organization), $2010 \mathrm{http}: / /$ www.fao.org/newsroom/EN/news/

[17]. J. Gawander, Impact of climate change on sugar-cane production in Fiji (Fiji, WMO Bulletin), 2007, 56(1).

[18]. T. Deressa, R. Hassan, D Poonyth, Measuring the impact of climate change on South African Agriculture: A tutorial review, Proc. The Case of Sugarcane Growing Regions. Agrekon, 2005, 44(4), 1- 19.

[19]. A. C Nzeadibe, N. A Cukwuome, C. L Egbule and C. L Agu, Climate change awareness and adaptation in the niger delta region of Nigeria, Journal of African Technology network, 2011, 65-83.

[20]. S. Ishaya and I. B. Abaje, Indigenous peoples' perception on climate change and adaptation strategies in Jema'a local government area of Kaduna State, Nigeria, Journal of Geography and regional Planning, 1(8), 2008, 138-143.

[21]. T G. Apata, K. D Samuel and A. O Adeola, Analysis of climate change perception and adaptation among arable food crop farmers in south western Nigeria: A tutorial review, Proc. International Association of Agricultural Economists conference, Beijing, China, 2009.

[22]. E C Nze and O. R Ebo, Technological challenges of climate change adaptation in Nigeria: Insight from Enugu state. Journal of African Technology policy network. (52), 2011, 1-5.

[23]. Wikipedia, Lere, Kaduna State, 2014, available at www.en.wikipedia.org/../Lere_Kaduna_State retrieved on 20/10/15

[24]. N. Population Commission, National Population Commission Census Report (Federal Republic of Nigeria, Abuja), 2009

[25]. P A. Odjugo, Global and regional analysis of the causes and rate of climate change. A tutorial review, Proc. National Conference on Climate Change and Nigerian Environment, Department of Geography, University of Nsukka, Nsukka, Nigeria, 29th June - 2nd July, 2009.

[26]. P A Odjugo, Climate change and global warming: the Nigerian perspective: Journal of Sustainable Development and Evironmental Protection (1) 1,2011

[27]. A Idowu, S.O. Ayoola and A. I Ikenweiwe, Impact of climate change in Nigeria: Iranica Journal of Energy and Environment, 2(2), $2011,145-152$

[28]. C Mishek, Potential impacts of climate change in sugarcane and mitigation strategies in Zimbabwe: African Journal of Agricultural Research, 8(23) 2013, 2814 - 2818 